\title{
INFLUENCE OF ABSORPTIVE CAPACITY ON INNOVATION: A SYSTEMATIC LITERATURE REVIEW
}

\author{
ANDREI MIKHAILOV ${ }^{1}$ \\ (iD) https://orcid.org/0000-0003-1465-1958 \\ FERNANDA M. REICHERT ${ }^{2}$ \\ (iD) https://orcid.org/0000-0002-5639-5879
}

To cite this paper: Mikhailov, A., \& Reichert, F. M. (2019). Influence of absorptive capacity on innovation: A systematic literature review. Revista de Administração Mackenzie, 20(6). doi:10.1590/ 1678-6971/eRAMD190033

Submission: Mar. 14, 2019. Acceptance: Aug. 23, 2019.

1 Universidade do Vale do Rio dos Sinos (Unisinos), Porto Alegre, RS, Brazil.

2 Universidade Federal do Rio Grande do Sul (UFRGS), Porto Alegre, RS, Brazil.

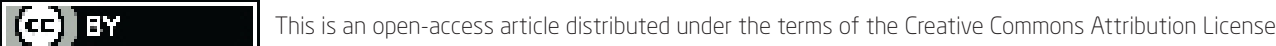

\footnotetext{
This paper may be copied, distributed, displayed, transmitted or adapted if provided, in a clear and explicit way, the name of the journal, the edition, the year and the pages on which the paper was originally published, but not suggesting that RAM endorses paper reuse. This licensing term should be made explicit in cases of reuse or distribution to third parties. It is not allowed the use for commercial purposes.

Este artigo pode ser copiado, distribuído, exibido, transmitido ou adaptado desde que citados, de forma clara e explícita, o nome da revista, a edição, o ano e as páginas nas quais o artigo foi publicado originalmente, mas sem sugerir que a RAM endosse a reutilização do artigo. Esse termo de licenciamento deve ser explicitado para os casos de reutilização ou distribuição para terceiros. Não é permitido o uso para fins comerciais.
} 


\section{ABSTRACT}

Purpose: The purpose of this paper is to reveal how quantitative empirical studies approach the direct influence of absorptive capacity (AC) on innovation. The AC research field continues to be subject to the phenomenon of reification, since it is still quite scattered.

Originality/value: The article contributes to AC's theoretical approach by compiling a set of forces with AC's direct influence on innovation. This evaluation has revealed detailed information about this relationship, such as the AC approach used and situations in which it acts as a moderating force in a relationship. Thus, we suggest a structure of influence of AC on innovation.

Design/methodology/approach: Systematic literature review based on Tranfield, Denyer, and Smart's (2003) method was applied. From an initial sample of 231 articles, 37 empirical studies were selected for analysis. We analyzed the AC's influence on innovation in each paper, as well as the forces that affect that influence.

Findings: The results suggest that AC dynamic approach may become dominant within AC and innovation literature, as the number of studies that use this approach grows constantly. However, the validated measurement models proposed by several AC scholars are still underused by most studies. Many empirical studies tend to adapt existing measurement models according to idiosyncratic research needs. In addition, as expected, we identified that intra-firm factors might be as important as environmental factors in transforming firms' AC into innovation.

\section{KEYWORDS}

Absorptive capacity. Innovation. Systematic literature review. Capabilities. Framework. 


\section{INTRODUCTION}

In this paper, we look into the effects of absorptive capacity (AC) on innovation through a systematic literature review. The expression "absorptive capacity" was established by Cohen and Levinthal (1990) in the paper entitled "Absorptive capacity: a new perspective on learning and innovation". In this work, Cohen and Levinthal (1990) explained how absorptive capacity could foster innovation and innovative performance within the companies. Twelve years later, Zahra and George (2002) proposed a new model, in which they treated AC as a dynamic capability, and stated that AC helps companies to sustain competitive advantages over competitors, by increasing flexibility, innovation and firms' performance. AC is also the "bedrock" of innovation theories, as well as a strong predictor of innovation and knowledge transfer within the firms (Koch \& Strotmann, 2008; Zou, Ertug, \& George, 2018).

AC theory presents theoretical multidimensionality, which promotes its diffusion through integration with other theories, such as network theory, knowledge-based theory, and dynamic capability theory (Apriliyanti \& Alon, 2017). Likewise, the existence of different models of AC contributes to the dispersion of studies in theoretical terms. Therefore, the task of translating each element of the theoretical models into empirical constructs is quite challenging.

After the mid-2000s, the number of articles using AC concept passed through a significant increase. For instance, Lane, Koka, and Pathak (2006) pointed out that, since the introduction of the concept, more than 900 peerreviewed academic papers were published. Some years later, Volberda, Foss, and Lyles (2010) identified 1213 articles published between 1992 and 2005. To date, only in business and management academic fields, more than 2000 journal articles indexed by Isi Web of Knowledge have been published. Possibly, for that reason, business and management scholars had conducted a number of literature reviews on AC in order to shed light on the state of academic knowledge in this field (Apriliyanti \& Alon, 2017; Lane et al., 2006; Volberda et al., 2010).

Along these years, AC scholars have identified main AC theoretical perspectives (Volberda et al., 2010), AC construct approaches (Lane et al., 2006) and research streams (Apriliyanti \& Alon, 2017). However, they have not pointed out the close relationship between AC and innovation. For instance, Rossetto, Carvalho, Bernardes, and Borini (2017) attempted to address the AC and innovation research stream, but their study focused 
mainly on bibliometric aspects of academic literature, rather than on the influence of AC on innovation itself. In this sense, the AC literature reviews failed to reveal the in-depth aspects and conditions under which AC directly influences innovation, as well as to provide detailed description on how the empirical investigation of the impact of AC on innovation takes place.

Theoretical studies argued that forces such as social integration mechanisms, appropriability regimes, and past experiences act as moderators of AC and innovation relationships. Lau and Lo (2015) state that AC is often studied as an antecedent or a moderator of innovation performance, but not as the factor of direct influence on innovation. Still, a number of empirical studies show some forces that affect the influence of AC on innovation, such as organizational learning (Garcia-Morales, Ruiz-Moreno, \& Llorens-Montes, 2007), technological turbulence (Su et al., 2013) and innovative culture (Ali \& Park, 2016). Therefore, it becomes crucial to investigate which are actually the empirically proven conditions that favor, as well as those that reduce, the direct effect of AC on innovation.

There are many statistically validated instruments for AC measurement (Jansen, Van Den Bosch, \& Volberda, 2005; Camisón \& Forés, 2010; Jimenez-Barrionuevo, García-Morales, \& Molina, 2011; Flatten, Engelen, Zahra, \& Brettel, 2011). However, it remains unclear which constructs are used to investigate the impact of AC on different aspects of firms' innovation, which AC measures and data analysis procedures are applied in these studies, and which AC dimensions and capabilities are usually addressed in the peerreviewed publications.

The ever highly dynamic markets increase the pressure on firms to innovate constantly (Nilsson \& Ritzén, 2014). It is crucial, then, that firms recognize their environment as a source for new ideas. Firms' AC contributes to the transformation of an absorbed knowledge into novelties that, eventually, lead to firms' innovative performance (Cohen \& Levinthal, 1990; Todorova \& Durisin, 2007; Chen, Lin, \& Chang, 2009). Therefore, it is essential to investigate which are the empirically proven conditions that favor, as well as those that reduce, the direct effect of AC on innovation. To fill this gap, we propose the following research question:

- How do the empirical articles investigate the direct influence of AC on innovation and what are their primary results?

In order to answer this question, we carried out a systematic literature review based on Tranfield et al.'s (2003) methodological procedures. Our 
aim was to verify the impact of AC on innovation, as well as the research methods, used in peer-reviewed articles in top journals. Additionally, we verified the forces that interfere in the influence of AC on innovation, the concepts applied to AC, and the constructs' elaboration, and data analysis procedures and abstract analysis.

The present study contributes to the literature by compiling a set of forces that influence the direct influence of $\mathrm{AC}$ on innovation. In addition, unlike previous reviews, we focus entirely on the direct influence of $\mathrm{AC}$ on innovation. In doing so, it is possible to reveal detailed information on this relationship, such as applied AC approach and situations in which AC acts as a moderator force. Finally, we suggest that intra-firm aspects could be as important for the translation of AC into innovation as the environmental factors.

This paper is structured as follows: after the introduction, we discuss current AC literature. Then, we present and discuss papers that connect AC to innovation. Section 4 shows the method used to conduct the systematic literature review. The main findings are included in section 5 , followed by the discussion of the results in section 6 . Conclusions and avenues for future research are made in section 7 .

\section{ABSORPTIVE CAPACITY THEORETICAL APPROACH}

Cohen and Levinthal (1990, p. 128) define AC as "the ability of a firm to recognize the value of new, external information, assimilate it, and apply it to commercial ends". They stated that research and development (R\&D) spillovers can increase the firms' ability to identify, assimilate and exploit knowledge from the environment. As shown at Figure 2.1, Zahra and George (2002) say that AC is a dynamic capability and split it into two dimensions: potential AC (PAC) and realized AC (RAC) and four capabilities: acquisition, assimilation, transformation, and exploitation. 


\section{(Figure 2.1)}

AC CONCEPTUAL MODEL ACCORDING TO ZAHRA AND GEORGE (2002)

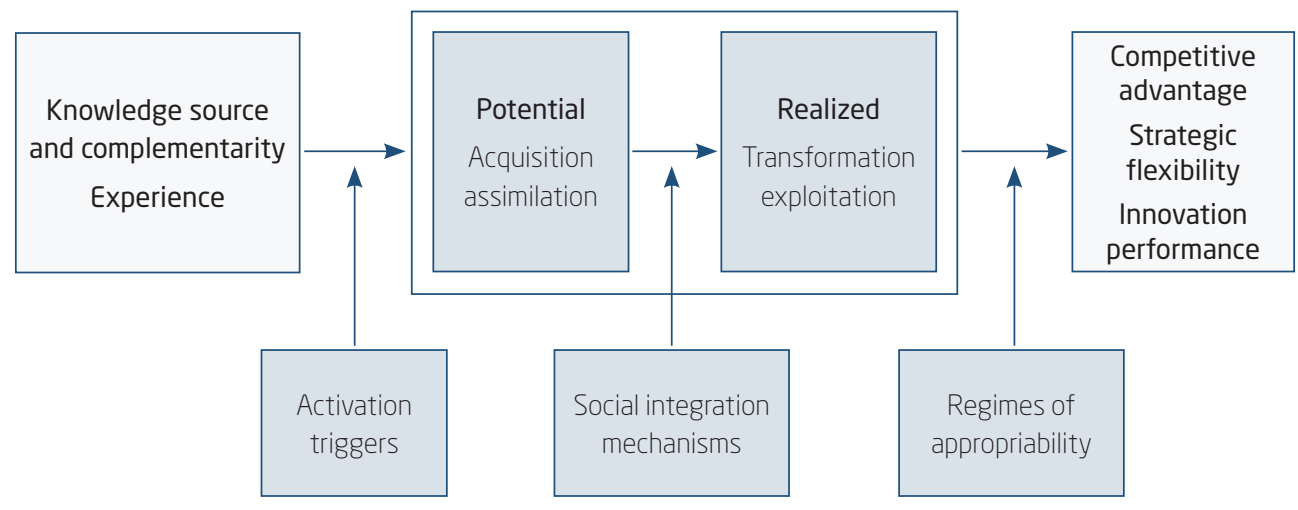

Source: Zahra and George (2002).

Later, Todorova, and Durisin (2007) proposed a partial return to the original model of AC by reintroducing the value recognition of external information, and by defining the $\mathrm{AC}$ as a construct of five capabilities. Thus, first, the firm needs to recognize the value of external knowledge and then, the four capabilities' process begins. Second, the assimilation occurs when the new information fits the existing cognitive structures. However, when the new knowledge cannot be assimilated through existing cognitive structures, it requires a transformation process of the current mental structures (Todorova \& Durisin, 2007).

Still, changes introduced by Todorova and Durisin (2007) are subject to a debate within the research community. Zahra and George (2002) posit that prior experience is crucial, in order to allow the AC impact on innovation and performance. Experiences of the firm influence the development of its acquisition capabilities. Similarly, the exposure to diverse knowledge sources per se does not guarantee a PAC development, once it needs to have knowledge complementarity with firms' activities (Zahra \& George, 2002). Lewin, Massini, and Peeters (2011) addressed the specific organizational routines and processes that constitute AC. Thus, facilitating variation, managing internal selection regimes, sharing knowledge, and superior practices across the organizations are among these underlying metaroutines. Metaroutines in organizations can be expressed in similar or in different ways (Lewin et al., 2011).

Lane et al. (2006) proposed a model of exploratory learning, transformation learning and exploitative learning. The exploratory dimension 
includes the recognition and understanding of the value of new information. Then, external information is assimilated through a transformation process at the individual and firm levels. Finally, the exploitative learning allows the application of new knowledge to generate results. Learning mechanisms are essential for the firms to be innovative (Zawislak, Cherubini Alves, TelloGamarra, Barbieux, \& Reichert, 2012; Zollo \& Winter, 2002), therefore it is essential to understand the relationship between $\mathrm{AC}$ and innovation better.

\section{ABSORPTIVE CAPACITY AND INNOVATION STUDIES}

Weak appropriability regime within the industry and the high knowledge spillovers availability will stimulate the firms to increase their R\&D investment (Cohen \& Levinthal, 1989). This, in turn, will increase firms' AC and therefore impact on firms' innovative performance (Cohen \& Levinthal, 1990; Todorova \& Durisin, 2007; Volberda et al., 2010; Zahra \& George, 2002).

AC and innovation studies show that AC positively affects innovative performance. These studies can be divided into three categories. The first one includes theoretical works (Lane et al., 2006; Todorova \& Durisin, 2007; Zahra \& George, 2002). The articles from this group highlight forces such as dynamism and competitiveness, knowledge characteristics, appropriability regimes, environmental conditions, organizational structure and $\mathrm{R} \& \mathrm{D}$ intensity (Cohen \& Levinthal, 1990; Lewin et al., 2011; Todorova \& Durisin, 2007; Volberda et al., 2010; Zahra \& George, 2002) that moderate the aforementioned relationship.

The second category of papers relates to empirical studies that assumed the positive influence of AC on innovation in the proposed models without, in fact, testing this assumption (Fosfuri \& Tribo, 2008). For instance, Fosfuri and Tribo (2008), through econometric analysis, tested the hypothesis of the positive moderation of social integration mechanisms on the influence of PAC on innovation. However, the hypothesis of the influence of PAC on innovation was not identified, despite the presence of $\mathrm{AC}$ and innovation at the research model.

The third group includes articles that aimed to check the direct influence of AC on innovation (Kostopoulos, Papalexandris, Papachroni, \& Ioannou, 2011; Murovec \& Prondan, 2009; Tsai, 2001). This group is particularly interesting because it quantitatively measures the impact of AC, its dimensions or capabilities, on innovation. 
One more question that remains unanswered within AC and innovation relationship studies concerns the balance between different types of measures of AC. There are studies that use $R \& D$ related measures, such as R\&D expenditures (Escribano, Fosfuri, \& Tribó, 2009; Fores \& Camison, 2011), and R\&D expenditures and R\&D intensity (Cohen \& Levinthal, 1990; Tsai, 2001). Others apply education-related measures (Hervas-Oliver, Garrigos, \& Gil-Pechuan, 2011; Kostopoulos et al., 2011) and corporate-related training activities (Kostopoulos et al., 2011; Clausen, 2013; Dutse, 2013). Still, all of these measures are indirect; they are proxies that not fully explore the dynamic nature of AC (Volberda et al., 2010; Lau \& Lo, 2015).

In order to resolve this gap, AC scholars, by using Zahra and George's (2002) approach, created a number of AC direct measures operationalized through constructs (Jansen et al., 2005; Camisón \& Forés, 2010; Jiménez-Barrionuevo et al., 2011; Flatten et al., 2011). Thus, in order to improve AC measurements, scholars sought to evaluate firms' AC capabilities, rather than to use alternative measurements, such as R\&D or education-related measures. The difference among them is represented by the manner in which each capability is evaluated, as well as by the number of questions utilized for each dimension.

For instance, Jiménez-Barrionuvo et al. (2011) evaluated exploitation $\mathrm{AC}$ in terms of division of responsibilities division and the presence of companies' abilities to exploit information obtained from outside. Flatten et al.'s (2011) construct evaluated exploitation AC in terms of management support for the development of prototypes and the ability to effectively adapt to the new technologies. Jansen et al. (2005) used a six-items instrument for measuring knowledge exploitation, while Jiménez-Barrionuevo et al. (2011) used only two questions to evaluate the same capability. Considering that there are at least two types of different $\mathrm{AC}$ measures, the following question arises:

- Which AC measurement predominates in the AC and innovation literature?

It is important to evaluate coefficients of direct influence of AC on innovation. In fact, the only systematic literature review (SLR) that measures the influence of AC on different outcomes was performed by Zou et al. (2018). Thus, AC impacts on financial performance mediated by innovation and knowledge transfer were measured, but not the direct influence of AC on innovation (Zou et al., 2018). 


\section{METHOD AND MEASURES}

SLR, which is a key tool to manage the diversity of knowledge for a specific academic inquiry, was performed (Tranfield et al., 2003). According to Tranfield et al. (2003, p. 208), SLR allows to "map and to assess the existing intellectual territory, and to specify a research question to develop the existing body of knowledge further". The application of a methodology used in the medical sciences for management research helps to reduce its often seen subjectivity and biased information, as well as allows for a transparent and reproducible procedure (Mulrow, 1994; Perkmann et al., 2013; Tranfield et al., 2003).

\subsection{Review plan}

To collect data, we set a protocol for our research (Figure 4.1.1). The importance of protocol is that, on one hand, it should not compromise the researchers' ability to be creative in the literature review process and, on the other, it must ensure the reviews to be less open to researcher bias than the more traditional narrative reviews are (Tranfield et al., 2003).

The two most important and well-established peer-reviewed scientific literature databases, the ISI Web of Science (WoS) and Scopus, serve as source for the review. Figure 4.1.1 shows the articles selection criteria:

\section{(Figure 4.1.1) \\ SEARCH PROTOCOL}

\begin{tabular}{lll}
\hline \multicolumn{1}{c}{ Criteria } & \multicolumn{1}{c}{ Web of Science } & \multicolumn{1}{c}{ Scopus } \\
\hline Terms & $\begin{array}{l}\text { "absorptive capacit*" OR "absorptive } \\
\text { capabilit*" AND "innovat*" }\end{array}$ & $\begin{array}{l}\text { "absorptive capacit*" OR "absorptive } \\
\text { capabilit*" AND "innovat*" }\end{array}$ \\
\hline Field & Title $^{1}$ & Title \\
\hline Period & $1990-$ November 2017 & 1990 - November 2017 \\
\hline Document type & Journal article & Journal article \\
\hline Research/subject areas & Business, management & Business, management, and accounting \\
\hline Language & English & English \\
\hline
\end{tabular}

Source: Elaborated by the authors.

When starting SLR, we decided to apply the indicated keywords "Title, abstract and keywords". At the Web of Science only, 2031 articles were found. Due to the difficulty of making in-depth review of such number of studies, we decided to apply the same searching criteria only for "Title". Therefore, 130 articles at Scopus and 101 at the Web of Science were found. 
The application of the established criteria resulted in 130 articles from Scopus and 101 from the Web of Science. After reading the abstracts, 71 Scopus and 76 Web of Science articles were selected. After filtering repeated studies, researchers obtained 99 articles. During the brief reading of the 99 articles, 54 were discarded due to using AC only as a mediating or moderating variable. Researchers also discarded all articles in which it was not possible to identify a direct relationship between AC and innovation. Among those, it was possible to find some qualitative approach studies using a case study or multiple case studies, many of which were published in 2016 or 2017. An in-depth reading of 45 articles resulted in additional eight articles eliminated from the study. Four articles were removed because they did not propose the direct relationship between AC and innovation, but rather, they took it for granted in the studies' hypothesis. Two articles analyzed the influence of AC on innovation as the synergy effect with other variables. One article used $\mathrm{AC}$ only as a mediating variable, and one more did not describe the procedures for AC measures.

(Figure 4.1.2)

ARTICLES SELECTION RESEARCH PROCEDURES

\begin{tabular}{lc}
\multicolumn{1}{c}{ Activity } & Number of articles \\
\hline Search for keywords at Scopus and WoS & 231 \\
\hline Removal of the duplicates & 99 \\
\hline Brief reading of remaining articles & 45 \\
\hline Deep reading of remaining articles & 37 \\
\hline
\end{tabular}

Source: Elaborated by the authors.

\subsection{Research approach}

In addition to basic characterization including article title, authors, year of publication, journal, journal impact factor, number of citations, industry and country where the research was conducted, AC and related topics were added to the analysis. They are: 1 . AC approach; 2 . moderating and mediation forces acting on AC and innovation relationship; 3. other forces exercising direct influence on innovation; 4. data analysis procedures; and 5. key findings of each article. In addition, we analyzed elements such as the use of construct validation method and secondary data.

AC approach included: applied AC measures; studies used to create AC measures; impact of $\mathrm{AC}$ and its components on innovation. The use of 
NVivo 11 and IBM SPSS 17 software helped researchers to open the blackbox of the direct influence of AC on innovation.

\section{RESULTS ANALYSIS AND KEY FINDINGS}

The first study containing both the "absorptive capacity" and "innovation" in the title was conducted by Tsai (2001), where he investigated the effects of network position and AC on business unit innovation. The second study was published six years later, where Garcia-Morales et al. (2007) studied technology AC effects on organization learning, innovation, and performance. In total, the year 2017 comprises the largest number of articles (seven out of 37), followed by 2013 and 2015 (six each). In 2016, five articles were published and, in 2012 and 2014, two articles per year were published. Together, the 37 articles received 1,931 citations at the Web of Science and 2,415 at Scopus. Twenty-nine received at least one citation, and 19 received at least five citations in at least one of the databases. Among the articles without citations (eight), five were published in 2017. Figure 5.1 shows the most cited articles.

(Figure 5.1)

ARTICLES WITH THE HIGHEST NUMBER OF CITATIONS

\begin{tabular}{lclcrrr}
\multicolumn{1}{c}{ Authors } & Year & \multicolumn{1}{c}{ Journal } & $\begin{array}{c}\text { Impact } \\
\text { factor }\end{array}$ & WoS $^{2}$ & Sco \\
\hline Tsai & 2001 & Academy of Management Journal & 7.4 & 1294 & 1490 \\
\hline Chen, Lin, and Chang & 2009 & Industrial Marketing Management & 3.2 & 120 & 146 \\
\hline $\begin{array}{l}\text { Kostopoulos, Papalexandris, } \\
\text { Papachroni, and loannou }\end{array}$ & 2011 & Journal of Business Research & 3.4 & 93 & 113 \\
\hline Murovec and Prodan & 2009 & Technovation & 3.3 & 92 & 114 \\
\hline $\begin{array}{l}\text { Ritala and Hurmelinna- } \\
\text { Laukkanen }\end{array}$ & 2013 & $\begin{array}{l}\text { The Journal of Product Innovation } \\
\text { Management }\end{array}$ & 3.8 & 67 & 76 \\
\hline Arbussa and Coenders & 2007 & Research Policy & 4.5 & 62 & 70 \\
\hline
\end{tabular}

Source: Elaborated by the authors.

2 WOS column shows the number of citations that each article received on the Web of Science, while the Sco column shows the number of citations received by the articles on Scopus. 
The object of study in these articles are: firms from different sectors (18 out of 37) manufacturing firms (six out of 37), high-tech firms (five out of 37), companies from automotive industry (three out of 36), knowledge-intensive business services (KIBS) (two out of 37), banking industry, agribusiness sector (one each). In one case, it was not possible to identify the studied sector. Five studies were conducted in China, four in Spain, and three in Taiwan. Four articles collected data from more than one country. The other 21 studies analyzed firms from many places, including Finland, South Korea, Brazil, and Nigeria.

As observed in Figure 5.2, the most frequent word in the abstract of the selected articles is "knowledge" (4.77\%). Among the 15 most used words are, also, "organizational", "sources", "relationship", and "technology". This might indicate that, within AC studies, knowledge and learning theories interconnect with technological subjects (Apriliyanti \& Alon, 2017; Cohen \& Levinthal, 1990; Lewin et al., 2011; Volberda et al., 2010).

\section{(Figure 5.2)}

\section{WORD CLOUD OF THE 15 MOST FREQUENT WORDS THAT APPEARED IN ABSTRACT OF ARTICLES}

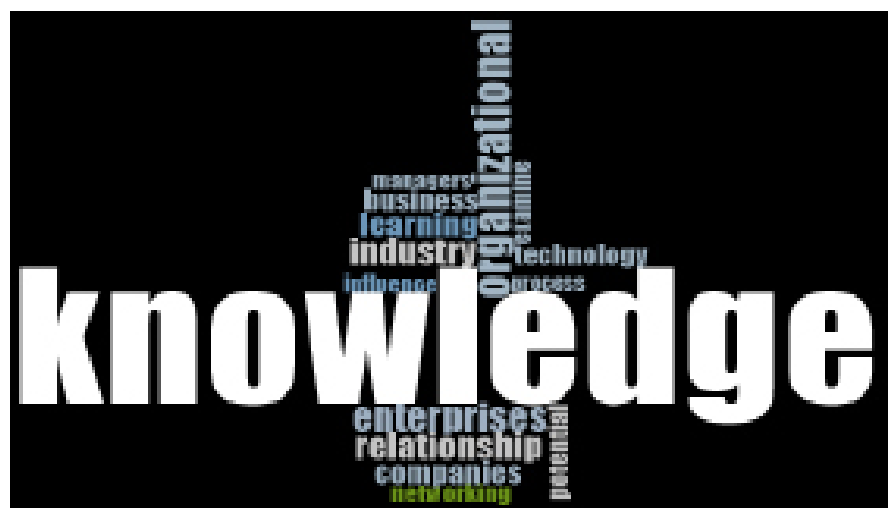

Source: Elaborated by the authors.

It is important to add that, in 21 studies, the AC was not the only force to directly influence innovation. In addition to AC, these studies analyzed the influence of knowledge inflows (De Zubielqui, Jones, \& Lester, 2016; Gao, Xu, \& Yang, 2008; Huang, Rice, \& Martin, 2015; Kostopoulos et al., 2011; Moilanen, Østbye, \& Woll, 2014; Scuotto, Del Giudice, \& Carayannis, 2017; Tseng, Chang Pai, \& Hung, 2011) and learning aspects (Chen et al., 2009; Garcia-Morales et al., 2007; Song, 2015; Su et al., 2013) 
on innovation. These results are in line with Apriliyanti and Alon (2017), who argued that knowledge transfer and organizational learning are in the AC citation map. Thus, one suggests that, in order to innovate, the firms also need learning aspects and access to required information sources to complement the AC.

\subsection{Articles' methodological approaches}

Thirty-five articles used quantitative research approach and used mixed methods. All articles used construct validation methods. Five studies used secondary data, of which, four analyzed data from the Community Innovation Survey (CIS) and one from the World Investment Climate Survey. Sixteen studies collected data from less than 200 observations, 10 articles used between 200 and 400, and 11 articles used a sample of more than 400 observations, half of them with the use of secondary data.

Structural equation modeling (SEM) was used by 23 articles. Regression analysis was used in 12 studies, including Heckman and Poisson regressions (Clausen, 2013), ordinary least square (OLS) regression (Su et al., 2013), hierarchical regression (Gao, Xu, \& Yang, 2008), tobit regression (Huang et al., 2015), pooled regression analysis (Tseng et al., 2011) and logit model (Arbussa \& Coenders, 2007). Factor analysis was used in seven cases. Some studies used more than one method. For instance, Ritala and Hurmelinna-Laukkanen (2013), while studying the incremental and radical innovation in the coopetition issue in Finland, applied exploratory factor analysis (EFA), followed by multiple multivariate regression analysis.

\subsection{Applied concepts and AC treatment}

Fifteen articles used their construct based on one specific study. Six articles used Flatten et al. (2011) construct and five used Jansen et al. (2005). The following studies were the base for one study each: Escribano et al. (2009), Liao, Frei, and Chen (2007), Cohen and Levinthal's (1990), and Zahra and George's (2002). Five articles created AC measures from two studies: Jansen et al.'s (2005) construct was used by three articles and Flatten et al.'s (2011) construct by two. Cohen and Levinthal's (1990) model was used together with an additional construct in two studies, one of which used Zahra and George's (2002) model. Fourteen articles used constructs based on a mix of different authors and definitions.

Some articles did not follow the referenced construct strictly. For instance, Huang et al. (2015) argued to use Zahra and George's (2002) 
model, but measured AC through the number of R\&D employees. All, except for four, articles used a term of either AC or correspondent acronymic, or its' dimension, while not focusing on the entire AC. Tseng et al. (2011) used the term "knowledge AC", Garcia-Morales et al. (2007) investigated "technology AC", and Murovec and Prodan (2009) divided AC into "demandpull" and "science-push".

Thirteen studies measured AC as a proxy. The first type of proxies include human resource (HR) related measures, such as employee motivation and ability (Wuryaningrat, 2013), personnel engaged in R\&D (Huang, Lin, Wu, \& Yu, 2015; Huang, Rice, \& Martin, 2015), employees with Bsc (Kostopoulos et al., 2011; Moilanen, Ostbye, \& Woll, 2014), training activities or investment in training (Clausen, 2013; Dutse, 2013; Kostopoulos et al., 2011). The second type of proxies includes measures of firms' R\&D in terms of R\&D expenditures/intensity (Tsai, 2001; Clausen, 2013) or R\&D activities (Zubielqui et al., 2016; Moilanen et al., 2014; Kostopoulos et al., 2011).

The R\&D activities and investment in HR lead to higher firms' AC (Cohen \& Levinthal, 1990). However, these measures are considered as inputs rather than AC itself. Therefore, Volberda et al. (2010) argue that proxy measures do not fully reflect the dynamic nature of AC.

\subsection{Analysis of the influence of AC on innovation}

As observed in Figure 5.3.1, 34 studies evaluated the influence of different AC capabilities on innovation. Twenty-five direct influences used $\mathrm{AC}$ as a whole construct while analyzing the impact of AC on innovation. Twenty studies analyzed the impact of AC on innovation in terms of its dimensions, that is, PAC and RAC (Gölgeci, Swiatowiec-Szczepanska, \& Raczkowski, 2017; Heil \& Enkel, 2015), as well as science-push and demandpull AC (Murovec \& Prondan, 2009).

The vast majority of analyzed forces (sixty-two out of seventy-nine) showed a positive influence on AC. It was demonstrated that both PAC and RAC have an impact on firms' product and process innovation (Ali and Park, 2016), as well as on innovation capabilities (Nazarpoori, 2017). AC as a whole construct showed a positive effect both on explorative and exploitative innovation (Limaj, Bernroider, \& Choudrie, 2016; Kohlbacher, Weitlaner, Hollosi, Grünwald, \& Grahsl, 2013), as well as on product innovation (Moilanen et al., 2014; Su et al., 2013) and innovation capabilities (Dutse, 2013; Wuryaningrat, 2013). 
However, while virtually all constructs of AC as a whole and dimensions of AC showed a positive influence on $\mathrm{AC}$, the proportion of studies that showed no-effect of individual's AC capabilities on innovation was relatively high (twelve out of thirty-four). That is the case of transformation AC, which showed no effect, neither on product, nor process and management innovation (Ali, Kan, \& Sarstedt, 2016) and assimilation AC on product (Engelman, Fracasso, Schmidt, \& Zen, 2017) and exploitative innovation (Enkel, Heil, Hengstler, \& Wirth, 2017).

\section{(Figure 5.3.1)}

DIRECT INFLUENCES OF AC ON INNOVATION AND THE WAY THE AC IS ANALYZED

\begin{tabular}{lcccc}
\hline Measurement of AC & Positive effect & Negative effect & No effect & Total \\
\hline Whole construct & 23 & 0 & 2 & 25 \\
\hline Dimensions & 17 & 0 & 3 & 20 \\
\hline Capabilities & 22 & 0 & 12 & 34 \\
\hline Total & 62 & 0 & 17 & $79^{4}$ \\
\hline
\end{tabular}

Source: Elaborated by the authors

The presence of a number of AC capabilities that individually showed no effect on innovation suggests that the increase of the given AC's capability alone may not be enough to affect the innovation positively. Therefore, it is suggested that firms that seek to innovate need to treat AC as a set of capabilities rather than only one given capability.

Likewise, we highlight that none of the identified forces showed a negative effect on innovation. Therefore, it seems that in most cases the positive influence of AC on a firm's innovation may remain unquestionable.

\subsection{Moderation and mediation forces}

As observed in Figure 5.3.1, the majority of forces enhance the influence of AC on innovation. That is the case of organization learning, appropriability regime, and social network sites. The technological turbulence, cultural barriers, and autonomous $\mathrm{R} \& \mathrm{D}$ climate decrease the influence of AC on innovation. In turn, the moderation force of organizational culture intelligence had no effect on innovation and innovative culture showed influence only on process and management innovation and organizational 
culture intelligence increased the influence of PAC and not RAC on innovation. Despite enhancing product innovation, there was no effect on process and management innovation. The influence of dynamism and competition were positive in the case of explorative innovation and negative for exploitative innovation.

From these results, we can conclude that, in general, the influence of $\mathrm{AC}$ on innovation is affected by a number of different forces and the influence of each moderation force requires further analysis.

\section{(Figure 5.4.1)}

MEDIATION AND MODERATION FORCES ACTING ON AC AND INNOVATION RELATIONSHIP

\begin{tabular}{|c|c|c|c|c|}
\hline Force & $A C$ & Innovation & Influence & Authors \\
\hline Appropriability regime & PAC & $\begin{array}{l}\text { Incremental } \\
\text { radical }\end{array}$ & Positive & $\begin{array}{l}\text { Ritala and Hurmelinna-Laukkanen } \\
\text { (2013) }\end{array}$ \\
\hline Autonomous R\&D climate & $A C$ & Innovation & Negative & Huang et al. (2015) \\
\hline Cultural barriers (CB) & PAC & Innovation & Negative & Leal-Rodríguez et al. (2014) \\
\hline $\begin{array}{l}\text { Dynamism and competition } \\
\text { in } B C s\end{array}$ & $A C$ & Explorative & Positive & Kohlbacher et al. (2013) \\
\hline $\begin{array}{l}\text { Dynamism and competition } \\
\text { in } B C s\end{array}$ & $A C$ & Exploitative & Negative & Kohlbacher et al. (2013) \\
\hline Innovative culture (IC) & PAC & $\begin{array}{l}\text { Process } \\
\text { management }\end{array}$ & Positive & Ali and Park (2016) \\
\hline Innovative culture (IC) & PAC & Product & No effect & Ali and Park (2016) \\
\hline Innovative culture (IC) & RAC & $\begin{array}{l}\text { Process } \\
\text { management }\end{array}$ & Positive & Ali and Park (2016) \\
\hline Innovative culture (IC) & RAC & Product & No effect & Ali and Park (2016) \\
\hline $\begin{array}{l}\text { Organizational cultural } \\
\text { intelligence }\end{array}$ & $A C$ & Innovation & Positive & $\begin{array}{l}\text { Gölgeci, Swiatowiec-Szczepanska, } \\
\text { and Raczkowski (2017) }\end{array}$ \\
\hline $\begin{array}{l}\text { Organizational cultural } \\
\text { intelligence }\end{array}$ & PAC & $\begin{array}{l}\text { Incremental } \\
\text { radical }\end{array}$ & Positive & Gölgeci et al. (2017) \\
\hline Organizational learning & $A C$ & Innovation & Negative & Garcia-Morales et al. (2007) \\
\hline Social network sites & PAC & Innovation & Negative & Scuotto et al. (2017) \\
\hline Technological turbulence & $A C$ & Explorative & Positive & Su et al. (2013) \\
\hline
\end{tabular}




\subsection{Framework}

By analyzing the 37 empirical articles, we suggest a framework to approach the influence of $\mathrm{AC}$ on innovation.

\section{(Figure 5.5.1)}

\section{PROPOSED FRAMEWORK OF AC AND INNOVATION RELATIONSHIP}

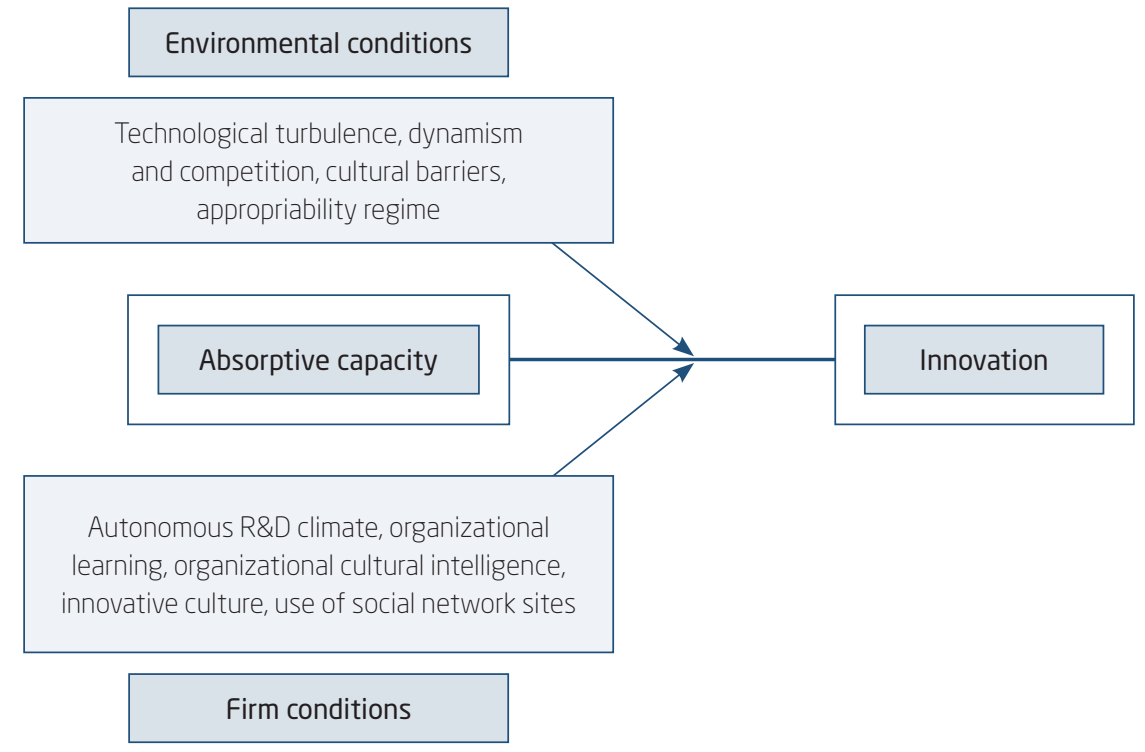

Source: Elaborated by the authors.

We highlight the importance of firms' internal conditions to moderate the impact of AC on innovation. This addition represents one of the theoretical advances of this article by empirically proving the importance of a number of firms' conditions to the impact of AC on innovation. Lewin et al. (2011) have already mentioned the importance of these factors, but their assumptions had mainly theoretical foundations. In this vein, intra-firm conditions, such as organizational learning, organizational cultural intelligence and innovative culture prove to affect the influence of $\mathrm{AC}$ on innovation.

The theoretical implication of this finding is that, in order to promote innovation within the company, it is not enough to develop AC by itself but also to pay attention on firms' internal conditions. This finding is in line with firms' dynamic capabilities approach (Teece, Pisano, \& Shuen, 1997; Zawislak et al., 2012), which stresses the importance of a specific firm's resources for innovation and competitiveness. The practical implication of 
this finding is that decisions of companies' owners and managers have considerable influence on transforming AC into innovation.

\section{DISCUSSION}

Volberda et al. (2010) stated that most empirical studies on AC used proxies to evaluate AC. According to our systematic review, this scenario is changing, as the majority of studies used AC capabilities measures. This switch makes it possible to empirically test the existing AC measurement models and, therefore, to create a loop of continuous testing and refinement of AC validated constructs. All analyzed studies used construct validation methods, therefore, AC research community is concerned with methodological rigor of their empirical studies.

However, we highlight that the majority of articles created AC measurement by relying on at least two previous academic studies. Therefore, it seems that scholars still need to develop more suitable AC measurement instruments that could attend to different contexts. The SLR allowed to suggest that empirical studies found that AC has a positive impact on innovation.

While the studies on the beginning of the period tended to analyze the influence of $\mathrm{AC}$ as a whole on innovation itself, the last two years showed some unprecedentedly detailed studies of the influence of specific AC capabilities on specific types of innovation (i.e., product, process). Thus, the $\mathrm{AC}$ and innovation studies appear to move towards a more detailed AC and innovation relationship analysis.

By conducting this study, we identified two main types of analysis applied in the studies: structural equation modeling (SEM) and regression analysis. In addition, we discovered that in many cases, the AC direct influence on innovation is complemented by the direct influence on innovation of at least one more variable, such as knowledge or organizational learning. These findings suggest that AC concepts and theory are cross-sectional to other theories such as knowledge management and organizational learning (Apriliyanti \& Alon, 2017; Volberda et al., 2010). Hence, we argue that AC scholars need to be aware of these theories once studying innovation.

The most important statement of the present study is that firms' internal conditions can be as important as environmental conditions in order to translate AC into innovation. Therefore, this finding aligns with dynamic capabilities (Teece et al., 1997; Reichert, Torugsa, Zawislak, \& Arundel, 2016; Alves, Barbieux, Reichert, Tello-Gamara, \& Zawislak, 2017) approaches, 
which understand firms' internal assets and capabilities as the most valuable innovation source. This finding supports the importance of improving firms' capabilities for strategic management.

Finally, following Lane et al.'s (2006) statement about the AC articles citation analysis, who argued that AC field is subject to reification, we highlight that most of the analyzed articles are not cited by any subsequent study from the present SLR. Therefore, we stress that the "reification" phenomena of the AC and innovation field is still present (Lane et al., 2006). One of the possible reasons for that concerns the number of scientific fields that use AC theory. These academic fields include capabilities and knowledge-related theories, as well as information systems management. Perhaps that is the reason for the presence of such a large number of articles that use AC theory. However, it will take time for the research community to evaluate whether the "reification" of AC and innovation field is for good or for bad.

\section{CONCLUSIONS AND AVENUE FOR FUTURE RESEARCH}

As expected, we found that, overall, AC does have a positive effect on innovation, despite some AC capabilities showing no effect on this relationship (i.e., assimilation capability in Engelman's et al. (2017) and Enkel et al.'s (2017) studies, and transformation capability in Ali et al.'s (2016) study).

AC and innovation literature is moving towards a higher methodological rigor and more dynamic $\mathrm{AC}$ measures. It means that those scholars who want to promote theoretical and empirical advances in this field need to be aware of research methods and to be keen in statistical tools.

Results of the SLR suggest the importance of the firm's internal aspects for transforming AC into innovation. Therefore, innovation policymakers should encourage firms to engage more in learning capabilities and internal processes that could enhance their AC. Likewise, managers need to be proactive in improving firms' AC if they want to achieve proper innovation outcomes.

Analyzed articles showed refinement in terms of innovation and AC types analyzed, within the academic field scholars and AC researchers should pay attention on the transformations within AC and innovation fields. The present study, applied structured systematical literature review based on Tranfield et al. (2003) to guarantee methodological rigor. In this sense, we hope that the AC and innovation field, as well as business and management in general, will continue to move towards more detailed reviews of the relationship between $\mathrm{AC}$ and innovation. We defend the 
use SLR instead of traditional literature reviews for analyzing the AC and innovation field literature, in order to guarantee proper replicability and comparability of the results. Finally, we intend that our proposed framework of the influence of AC on innovation serves to other scholars to investigate more precisely this issue.

The present study presents some limitations. For instance, due to the reduced number of analyzed articles, our results cannot be generalized to the whole field of AC and innovation studies. Likewise, each specific mediation or moderation that pointed out mediation or moderation forces of the influence of AC on innovation was stated by a small number of studies. This article did not address the different industries and sectors, neither controlled the firm size in order to check whether firms' and environmental forces are the same for different contexts.

For future research, we suggest the evaluation of other aspects of AC, such as its antecedents, as well as of the impact of AC on firms' competitiveness. In addition, future reviews could include meta-synthesis in order to enrich the scope of the analyzed scientific studies. As the nature of innovation within high-tech and low-tech industries are different (Reichert et al., 2016), mapping the different patterns of AC influence on innovation in these industries represents an opportunity for academic scholars. Thus, further studies on the quantification and deeper comprehension of the impact of $\mathrm{AC}$ on innovation and its adjacent constructs are still required.

Since AC impacts on innovation, results from the present study and all studies to come on the matter should contribute to enhancing firms' competitiveness and, hence, economic development.

\section{INFLUÊNCIA DA CAPACIDADE ABSORTIVA SOBRE INOVAÇÃO: UMA REVISÃO SISTEMÁTICA DE LITERATURA}

\section{$\int$ RESUMO}

Objetivo: O objetivo deste artigo é revelar como os estudos empíricos quantitativos abordam a influência direta da capacidade absortiva (CA) na inovação. Os autores argumentam que o campo de pesquisa em CA continua sendo sujeito ao fenômeno da reificação, já que este campo ainda é bastante disperso. 
Originalidade/valor: O artigo contribui para a abordagem teórica da CA ao compilar um conjunto de forças com influência direta da CA na inovação. Essa avaliação permitiu revelar informações detalhadas sobre essa relação, tais como sobre a abordagem da CA utilizada e sobre situações nas quais ela age como uma força moderadora de uma relação. Assim, sugere-se uma estrutura de influência do CA na inovação.

Design/metodologia/abordagem: O artigo é uma revisão sistemática da literatura com base no método de Tranfield, Denyer e Smart (2003). A partir da amostra inicial de 231 artigos, foram selecionados 37 estudos empíricos. Os pesquisadores analisaram a influência da CA na inovação em cada artigo, bem como as forças que afetam essa influência.

Resultados: Os resultados sugerem que a abordagem dinâmica da CA pode se tornar dominante na literatura sobre CA e inovação, já que o número de estudos que utilizam essa abordagem cresce constantemente. Entretanto, os modelos de mensuração validados propostos por diversos estudiosos da AC ainda são subutilizados pela maioria dos estudos. Muitos estudos empíricos tendem a adaptar os modelos de medição existentes de acordo com as necessidades idiossincráticas de investigação. Além disso, como esperado, verificou-se que fatores intrafirma podem ser tão importantes quanto fatores ambientais para transformar a CA das empresas em inovação.

\section{PALAVRAS-CHAVE}

Capacidade absortiva. Inovação. Revisão sistemática da literatura. Capacidades. Framework.

\section{REFERENCES}

Ali, M., Kan, K. A. S., \& Sarstedt, M. (2016). Direct and configurational paths of absorptive capacity and organizational innovation to successful organizational performance. Journal of Business Research, 69(11), 5317-5323. doi:10.1016/j.jbusres.2016.04.131

Ali, M., \& Park, K. (2016). The mediating role of an innovative culture in the relationship between absorptive capacity and technical and non-technical innovation. Journal of Business Research, 69(5), 1669-1675. doi:10.1016/j. jbusres.2015.10.036 
Alves, A. C., Barbieux, D., Reichert, F. M., Tello-Gamara, J., \& Zawislak, P. A. (2017). Innovation and dynamic capabilities of the firm: Defining an assessment model. Revista de Administração de Empresas, 57(3), 232-244. doi:10.1590/s0034-759020170304

Apriliyanti, I. D., \& Alon, I. (2017). Bibliometric analysis of absorptive capacity. International Business Review, 26, 896-907. doi:10.1016/j.ibusrev. 2017.02.007

Arbussa, A., \& Coenders, G. (2007). Innovation activities, use of appropriation instruments and absorptive capacity: Evidence from Spanish firms. Research Policy, 36, 1545-1558. doi:10.1016/j.respol.2007.04.013

Camisón, C., \& Forés, B. (2010). Knowledge absorptive capacity: New insights for its conceptualization and measurement. Journal of Business Research, 63(7), 707-715. doi:10.1016/j.jbusres.2009.04.022

Chen, Y.-S., Lin, M.-J. J., \& Chang, C.-H. (2009). The positive effects of relationship learning and $\mathrm{AC}$ on innovation performance and competitive advantage in industrial markets. Industrial Marketing Management, 38(2), 152-158. doi:10.1016/j.indmarman.2008.12.003

Clausen, T. H. (2013). External knowledge sourcing from innovation cooperation and the role of absorptive capacity: Empirical evidence from Norway and Sweden. Technology Analysis and Strategic Management, 25(1), 57-70. doi:10.1080/09537325.2012.751009

Cohen, W. M., \& Levinthal, D. A. (1990). Absorptive capacity: A new perspective on learning and innovation. Administrative Science Quarterly, 35(1), 128-152. doi: $10.2307 / 2393553$

De Zubielqui, G. C., Jones, J., \& Lester, L. (2016). Knowledge inflows from market- and science-based actors, absorptive capacity, innovation and performance: A study of SMES. International Journal of Innovation Management, 20(6), 1650055. doi:10.1142/S1363919616500559

Dutse, A. Y. (2013). Linking AC with innovative capabilities: A survey of manufacturing firms in Nigeria. International Journal of Technology Management \& Sustainable Development, 12(2), 167-183. doi:10.1386/tmsd.12.2.167_1

Engelman, R. M., Fracasso, E. M., Schmidt, S., \& Zen, A. C. (2017). Intellectual capital, absorptive capacity and product innovation. Management Decision, 55(3), 474-490. doi:10.1108/MD-05-2016-0315

Enkel, E., Heil, S., Hengstler, M., \& Wirth, H. (2017). Exploratory and exploitative innovation: To what extent do the dimensions of individual level absorptive capacity contribute? Technovation, 60-61, 29-38. doi:10.10 16/j.technovation.2016.08.002 
Escribano, A., Fosfuri, A., \& Tribó, J. A. (2009). Managing external knowledge flows: The moderating role of absorptive capacity. Research Policy, 38(1), 96-105. doi:10.1016/j.respol.2008.10.022

Flatten, T. C., Engelen, A., Zahra, S. A., \& Brettel, M. (2011). A measure of absorptive capacity: Scale development and validation. European Management Journal, 29(2), 98-116. doi:10.1016/j.emj.2010.11.002

Fores, B., \& Camison, C. (2011). The complementary effect of internal learning capacity and absorptive capacity on performance: The mediating role of innovation capacity. International Journal of Technology Management, 55(1-2), 66-86. doi:10.1504/IJTM.2011.041680

Fosfuri, A., \& Tribó, J. A. (2008). Exploring the antecedents of potential absorptive capacity and its impact on innovation performance. Omega International Journal of Management Science, 36(2), 173-187. doi:10.1016/j. omega.2006.06.012

Gao, S., Xu, K., \& Yang, J. (2008). Managerial ties, absorptive capacity, and innovation. Asia Pacific Journal of Management, 25(3), 395-412. doi:10.1007/ s10490-008-9096-1

Garcia-Morales, V. J., Ruiz-Moreno, A., \& Llorens-Montes, F. J. (2007). Effects of technology absorptive capacity and technology proactivity on organizational learning, innovation and performance: An empirical examination. Technology Analysis \& Strategic Management, 19(4), 527-558. doi:10. 1080/095thirty-seven320701403540

Gölgeci, I., Swiatowiec-Szczepanska, J., \& Raczkowski, K. (2017). How does cultural intelligence influence the relationships between potential and realised absorptive capacity and innovativeness? Evidence from Poland. Technology Analysis and Strategic Management, 29(8), 857-871. doi:10.1080/ 095thirty-seven325.2016.1245858

Heil, S., \& Enkel, E. (2015). Exercising opportunities for cross-industry innovation: How to support absorptive capacity in distant knowledge processing. International Journal of Innovation Management, 19(5), 1550048. doi:10.1142/S1363919615500486

Hervas-Oliver, J. L., Garrigos, J. A., \& Gil-Pechuan, I. (2011). Making sense of innovation by R\&D and non-R\&D innovators in low technology contexts: A forgotten lesson for policymakers. Technovation, 31(9), 427-446. doi:10.1016/j.technovation.2011.06.006

Huang, F., Rice, J., \& Martin, N. (2015). Does open innovation apply to China? Exploring the contingent role of external knowledge sources and internal absorptive capacity in Chinese large firms and SMEs. Journal of Management and Organization, 21(5), 594-613. doi:10.1017/jmo.2014.79 
Huang, K. F., Lin, K. H., Wu, L. Y., \& Yu, P. H. (2015). Absorptive capacity and autonomous R\&D climate roles in firm innovation. Journal of Business Research, 68(1), 87-94. doi:10.1016/j.jbusres.2014.05.002

Jansen, J. J., Van Den Bosch, F. A., \& Volberda, H. W. (2005). Managing potential and realized absorptive capacity: How do organizational antecedents matter? Academy of Management Journal, 48(6), 999-1015. doi:10. 5465/amj.2005.19573106

Jiménez-Barrionuevo, M. M., García-Morales, V. J., \& Molina, L. M. (2011). Validation of an instrument to measure absorptive capacity. Technovation, 31(5-6), 190-202. doi:10.1016/j.technovation.2010.12.002

Koch, A., \& Strotmann, H. (2008). AC and innovation in the knowledge intensive business service sector the knowledge intensive business service sector. Economics of Innovation and New Technology, 17(6), 511-531. doi:10. 1080/10438590701222987

Kohlbacher, M., Weitlaner, D., Hollosi, A., Grünwald, S., \& Grahsl, H. (2013). Innovation in clusters: Effects of absorptive capacity and environmental moderators. Competitiveness Review, 23(3), 199-217. doi:10.1108/ 10595421311319807

Kostopoulos, K., Papalexandris, A., Papachroni, M., \& Ioannou, G. (2011). Absorptive capacity, innovation, and financial performance. Journal of Business Research, 64(12), 1335-1343. doi:10.1016/j.jbusres.2010.12.005

Lane, P. J., Koka, B. R., \& Pathak, S. (2006). The reification of absorptive capacity: A critical review and rejuvenation of the construct. Academy of Management Review, 31 (4), 833-863. doi:10.5465/amr.2006.22527456

Lau, A. K. W., \& Lo, W. (2015). Regional innovation system, absorptive capacity and innovation performance: An empirical study. Technological Forecasting and Social Change, 92(C), 99-114. doi:10.1016/j.techfore.2014. 11.005

Leal-Rodríguez, A. L., Ariza-Montes, J. A., Roldán, J. L., \& Leal-Millán, A. G. (2014). Absorptive capacity, innovation and cultural barriers: A conditional mediation model. Journal of Business Research, 67 (5), 763-768. doi:10.1016/j. jbusres.2013.11.041

Leal-Rodríguez, A. L., Roldán, J. L., Ariza-Montes, J. A., \& Leal-Millán, A. (2014). From potential absorptive capacity to innovation outcomes in project teams: The conditional mediating role of the realized absorptive capacity in a relational learning context. International Journal of Project Management, 32 (6), 894-907. doi:10.1016/j.ijproman.2014.01.005 
Lewin, A. Y., Massini, S., \& Peeters, C. (2011). Microfoundations of internal and external absorptive capacity routines. Organization Science, 22 (1), 81-98. doi:10.1287/orsc. 1100.0525

Liao, S. H., Frei, W. C., \& Chen, C. C. (2007). Knowledge sharing, absorptive capacity, and innovation capability: An empirical study of Taiwan's knowledge-intensive industries. Journal of Information Science, 33(3), 340-359. doi: 10.1177/0165551506070739

Limaj, E., Bernroider, E. W. N., \& Choudrie, J. (2016). The impact of social information system governance, utilization, and capabilities on absorptive capacity and innovation: A case of Austrian SMEs. Information and Management, 53(3), 380-397. doi:10.1016/j.im.2015.12.003

Moilanen, M., Østbye, S., \& Woll, K. (2014). Non-R\&D SMEs: External knowledge, absorptive capacity and product innovation. Small Business Economics, 43(2), 447-462. doi:10.1007/s11187-014-9545-9

Mulrow, C. D. (1994). Systematic reviews: Rationale for systematic reviews. BMJ, 309(6954), 597-599. doi:10.1136/bmj.309.6954.597

Murovec, N., \& Prodan, I. (2009). Absorptive capacity, its determinants, and influence on innovation output: Cross-cultural validation of the structural model. Technovation, 29(12), 859-872. doi:10.1016/j.technovation.2009. 05.010

Nazarpoori, A. H. (2017). Survey the effects of intellectual capital and absorptive capacity on innovation capability (case study of Saipa Company in Tehran). International Journal of Innovation Management, 21 (3), 1750029. doi:10.1142/S1363919617500293

Nilsson, S., \& Ritzén, S. (2014). Exploring the use of innovation performance measurement to build innovation capability in a medical device company. Creativity and Innovation Management, 23(2), 183-198. doi:10.1111/caim. 12054

Perkmann, M., Tartari, V., McKelvey, M., Autio, E., Broström, A., D’Este, P., Fini, R., Geuna, A., Grimaldi, Hughes, A., Krabel, S., Kitson, M., Llerena, P., Lissoni, F., Salter, A., Sobrero, M . Academic engagement and commercialisation: A review of the literature on university-industry relations. Research Policy, 42 (2), 423-442. doi:10.1016/j.respol.2012.09.007

Reichert, F. M., Torugsa, A., Zawislak, P. A., \& Arundel, A. (2016). Exploring innovation success recipes in low-technology firms using fuzzy-set QCA. Journal of Business Research, 69(11), 5437-5441. doi:10.1016/j.jbusres. 2016.04.151 
Ritala, P., \& Hurmelinna-Laukkanen, P. (2013). Incremental and radical innovation in coopetition: The role of absorptive capacity and appropriability. The Journal of Product Innovation Management, 30(1), 154-169. doi:10.11 11/j.1540-5885.2012.00956.x

Rossetto, D. E., Carvalho, F. C. A., Bernardes, R. C., \& Borini, F. M. (2017). Absorptive capacity and innovation: An overview of international scientific production of last twenty-five years. International Journal of Innovation, (5), 97-113. doi:10.5585/iji.v5i1.172

Scuotto, V., Del Giudice, M., \& Carayannis, E. G. (2017). The effect of social networking sites and absorptive capacity on SMES' innovation performance. The Journal of Technology Transfer, 42(2), 409-424. doi:10.1007/ s10961-016-9517-0

Song, Z. H. (2015). Organizational learning, absorptive capacity, imitation and innovation: Empirical analyses of 115 firms across China. Chinese Management Studies, 9(1), 97-113. doi:10.1108/CMS-05-2014-0092

Su, Z., Ahlstrom, D., Li, J., \& Cheng, D. (2013). Knowledge creation capability, absorptive capacity, and product innovativeness. $R$ and $D$ Management, 43(5), 473-485. doi:10.1111/radm.12033

Teece, D. J., Pisano, G., \& Shuen, A. (1997). Dynamic capabilities and strategic management. Strategic Management Journal, 18(7), 509-533. doi:10.1002/(SICI) 1097-0266(199708) 18:7<509::AID-SMJ882>3.0. $\mathrm{CO} ; 2-\mathrm{Z}$

Todorova, G., \& Durisin, B. (2007). Absorptive capacity: Valuing a reconceptualization. Academy of Management Review, 32 (3), 774-786. doi:10.5465/ amr.2007.25275513

Tranfield, D., Denyer, D., \& Smart, P. (2003). Towards a methodology for developing evidence-informed management knowledge by means of systematic review. British Journal of Management, 14(3), 207-222. doi:10.11 11/1467-8551.00375

Tsai, W. (2001). Knowledge transfer in intraorganizational networks: Effects of network position and absorptive capacity on business unit innovation and performance. Academy of Management Journal, 44(5), 996-1004. doi:10. $2307 / 3069443$

Tseng, C., Chang Pai, D., \& Hung, C. (2011). Knowledge absorptive capacity and innovation performance in KIBS. Journal of Knowledge Management, 15(6), 971-983. doi:10.1108/13673271111179316

Volberda, H. W., Foss, N. J., \& Lyles, M. A. (2010). Perspective-absorbing the concept of absorptive capacity: How to realize its potential in the organization field. Organization Science, 21 (4), 931-951. doi:10.1287/orsc. 1090.0503 
Wuryaningrat, N. F. (2013). Knowledge sharing, absorptive capacity and innovation capabilities: An empirical study on small and medium enterprises in North Sulawesi, Indonesia. Gadjah Mada International Journal of Business, 15(1), 61-78. Recuperado de http://www.scopus.com/inward/ record.url? eid $=2$-s2.0 84877658729\&partnerID $=40 \& \mathrm{md} 5=42 \mathrm{~b} 2402 \mathrm{eccf}$ 49547ac7620d7ce42thirty-seven35

Zahra, S. A., \& George, G. (2002). Absorptive capacity: A review, reconceptualization, and extension. Academy of Management Review, 27(2), 185-203. doi:10.5465/AMR.2002.6587995

Zawislak, P. A., Cherubini Alves, A., Tello-Gamarra, J., Barbieux, D., \& Reichert, F. M. (2012). Innovation capability: From technology development to transaction capability. Journal of Technology Management \& Innovation, 7(2), 14-27. doi:10.4067/s0718-27242012000200002

Zollo, M., \& Winter, S. G. (2002). Deliberate learning and the evolution of dynamic capabilities. Organization Science, 13(3), 339-351. doi:10.1287/ orsc.13.3.339.2780

Zou, T., Ertug, G., \& George, G. (2018). The capacity to innovate: A metaanalysis of absorptive capacity. Innovation, 20(2), 87-121. doi:10.1080/14 479338.2018.1428105

\section{AUTHOR NOTES}

Andrei Mikhailov, Business School, Universidade do Vale do Rio dos Sinos (Unisinos); Fernanda M. Reichert, Management School, Universidade Federal do Rio Grande do Sul (UFRGS).

Andrei Mikhailov is now PhD. student at the Programa de Pós-Graduação em Administração of Universidade do Vale do Rio dos Sinos (Unisinos); and Fernanda M. Reichert is now assistant professor at the Management School of Universidade Federal do Rio Grande do Sul (UFRGS).

Correspondence concerning this article should be addressed to Andrei Mikhailov, Avenida Nilo Peçanha, 1600, room 214, Porto Alegre, Rio Grande do Sul, Brazil, CEP 91330-002.

E-mail: andreimikh@gmail.com

EDITORIAL BOARD

Editors-in-chief Janette Brunstein

Silvia Marcia Russi de Domênico

Associated Editor Glória Charão Ferreira

Technical Support

Vitória Batista Santos Silva

\section{EDITORIAL PRODUCTION}

Publishing Coordination Jéssica Dametta

Layout Designer

Emap

Language Editor

Daniel de Almeida Leão
Graphic Designer Libro 